\title{
Fishes and the environment of the Northern Ewaso Ng'iro in Kenya
}

Ray C. Schmidt (iD, Wanja D. Nyingi, Taylor E. Woods, Joseph Gathua \& Gilbert Kosgei
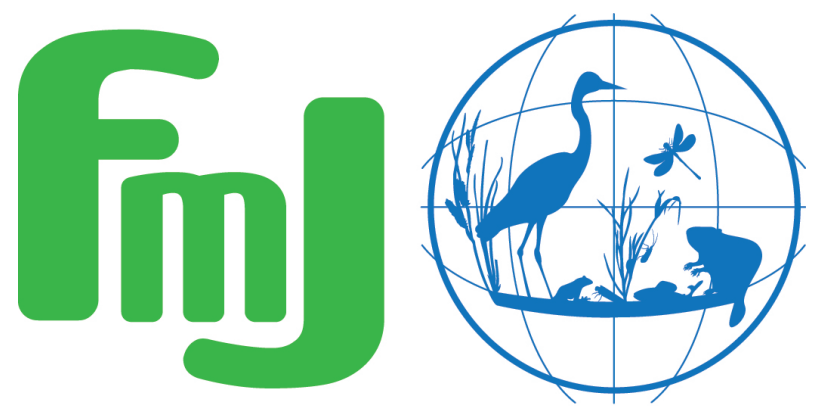

Freshwater Metadata Journal 



\section{Fishes and the environment of the Northern Ewaso $\mathrm{Ng}$ 'iro in Kenya}

Ray C. Schmidt 1,2 iD , Wanja D. Nyingi ${ }^{3}$ Taylor E. Woods ${ }^{4}$, Joseph Gathua ${ }^{3}$ \& Gilbert Kosgei $^{3}$

1 Randolph-Macon College, Ashland, USA; corresponding author: rschmidt@tulane.edu

2 National Museum of Natural History, Division of Fishes, Washington, USA

3 National Museums of Kenya, Nairobi, Kenya

4 University of Tennessee, Knoxville, USA

Please cite this paper as follows: Schmidt, R.C., Nyingi, W.D., Woods, T.E., Gathua, J. \& Kosgei, G., 2020. Fishes and the environment of the Northern Ewaso Ng'iro in Kenya. Freshwater Metadata Journal 49: 1-6. https://doi.org/10.15504/fmj.2020.49

Received: 2020-10-15 / Published: 2020-10-29

\section{Keywords}

Kenya, freshwater fishes, metacommunity, beta diversity

\section{Short description of the dataset/summary}

This dataset provides habitat, water parameters, and species of fishes collected monthly from 10 localities from 2015-2016. There are 101 collection events and over 10,000 fish specimens recorded.

\section{Short description of the dataset/summary (original/national language)}

This dataset provides habitat, water parameters, and species of fishes collected monthly from 10 localities from 2015-2016. There are 101 collection events and over 10,000 fish specimens recorded.

\section{General information}

dataset entry ID:

\section{name of the dataset:}

full name of the dataset:

full name of the datast (original/national language):

dataset short name:

type of dataset:

FWM 28
Fishes and the environment of the Northern Ewaso Ng'iro in Kenya Fishes and the environment of the Northern Ewaso Ng'iro in Kenya Fishes and habitat in the N. Ewaso Ng'iro species (taxonomic group) per site database including environmental information 
data type: point data/observation data

science keywords according to GCMD:

topic:

Biological Classification, Human Dimensions, Terrestrial Hydrosphere

ISO topic category according to ISO 19115:

Elevation, Inland Waters

INSPIRE keywords according to GEMET:

Habitats and biotopes, Land use

own science keywords:

meta-community, freshwater fishes, intermittent streams

funding:

This project was funded by the Smithsonian Institution through a postdoctoral fellowship to RCS.

\section{Technical and administrative specifications}

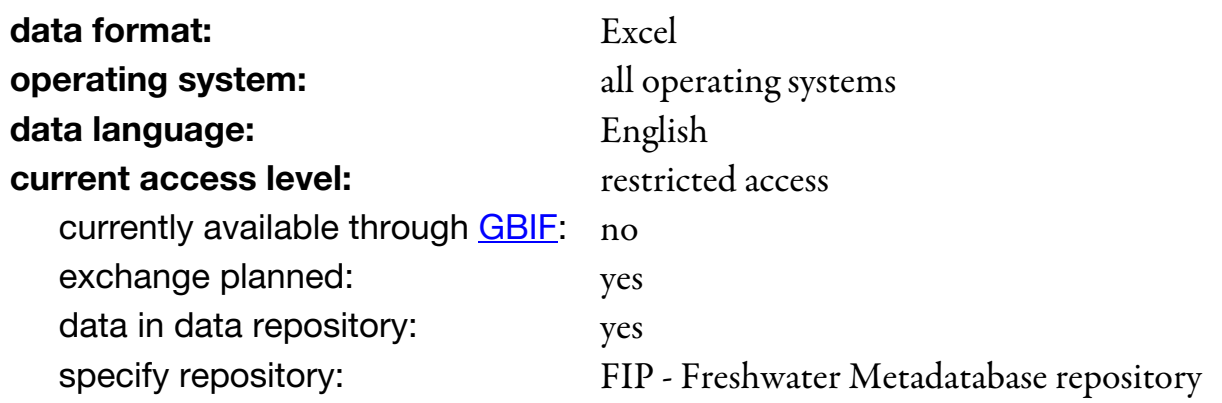

Do you plan to publish the data on the Freshwater Biodiversity Data Portal:

$\begin{array}{ll}\text { update level: } & \text { completed } \\ \text { documentation: } & \\ \text { type: } & \text { manual } \\ \text { language: } & \text { English }\end{array}$

\section{contact details:}

metadata contact person:

$\begin{array}{ll}\text { first, last name: } & \text { Ray Schmidt } \\ \text { phone: } & 4707285798 \\ \text { email: } & \text { rschmidt@tulane.edu } \\ \text { institution: } & \text { Smithsonian Institution } \\ \text { address: } & 4210 \text { Silver Hill Road, MRC 534 ?Fishes } \\ \text { postal code, city: } & 20746 \text { Suitland } \\ \text { province, state: } & \text { Maryland } \\ \text { country: } & \text { USA } \\ \text { web address: } & \text { https://raycschmidt.wixsite.com/fishdiversity } \\ \text { chnical contact person: } & \text { Ray Schmidt } \\ \text { first, last name: } & 4707285798 \\ \text { phone: } & \text { rschmidt@tulane.edu } \\ \text { email: } & \\ \text { ientific contact person: } & \text { Ray Schmidt } \\ \text { first, last name: } & 4707285798 \\ \text { phone: } & \text { rschmidt@tulane.edu } \\ \text { email: } & \end{array}$




\section{Intellectual property rights and citation}

dataset creator (data compiler):
contact name:
Ray C. Schmidt
contact email:
rschmidt@tulane.edu
contact institution:
Smithsonian Institution

\section{data contributors to/owners of this dataset:}

multiple

number:

5

\section{data contributor/owner 1:}

contact name:

contact email:

rschmidt@tulane.edu

contact institute:

Smithsonian Institution

criteria for using this part of the dataset:

The dataset is publicly available (data portal, data archive) and can be used without restrictions, but must be acknowledged and cited correctly.

\section{data contributor/owner 2:}

contact name:

contact email:

wanjanyingi@gmail.com

contact institute:

National Museums of Kenya

criteria for using this part of the dataset:

The dataset is publicly available (data portal, data archive) and can be used without restrictions, but must be acknowledged and cited correctly.

data contributor/owner 3:

contact name:

contact email: $\quad$ woodstaylorelizabeth@gmail.com

contact institute: University of Tennessee, Knoxville

criteria for using this part of the dataset:

The dataset is publicly available (data portal, data archive) and can be used without restrictions, but must be acknowledged and cited correctly.

data contributor/owner 4:

contact name:

contact email:

josephgathua@yahoo.com

contact institute:

National Museums of Kenya

criteria for using this part of the dataset:

The dataset is publicly available (data portal, data archive) and can be used without restrictions, but must be acknowledged and cited correctly.

data contributor/owner 5:

contact name:

contact email:

2kipscham@gmail.com

contact institute:

National Museums of Kenya

criteria for using this part of the dataset:

The dataset is publicly available (data portal, data archive) and can be used without restrictions, but must be acknowledged and cited correctly.

citation of this dataset:

author(s):

Schmidt, R.C., Nyingi, W.D., Woods, T., Gathua, J. \& Kosgei, G. title and journal (name, number, pages):

Data on the fishes and environment of the Northern Ewaso Ng'iro in Kenya from 2015 - 2016.

year:

2020 


\section{citation of the metadata:}

author(s):

Schmidt, R.C., Nyingi, W.D., Woods, T.E., Gathua, J. \& Kosgei, G. title and journal (name, number, pages):

Fishes and the environment of the Northern Ewaso Ng'iro in Kenya. Freshwater Metadata Journal 49: 1-6

year: 2020

doi:

https://doi.org/10.15504/fmj.2020.49

\section{dataset related references:}

reference 1:

author(s):

title:

year:

Nyingi, W.D.

Guide to Common Freshwater Fishes of Kenya. Moran (E.A.) Publishers

Limited. 136 pages

2013

\section{General data specifications}

regional coverage of the dataset:

spatial extent of the dataset:

catchment

continents:

Africa

spatial extent (bounding coordinates):

southernmost latitude $\left[{ }^{\circ}\right]$ :

$-.327541$

northernmost latitude $\left[^{\circ}\right]$ :

1.266292

westernmost longitude $\left[^{\circ}\right]$ :

36.373911

easternmost longitude $\left[{ }^{\circ}\right]$ :

39.490031

countries:

comments:

Africa: Kenya

Data generated from collections in the Northern Ewaso Ng'iro basin in Kenya from 2015 to 2016.

\section{ecosystem type:}

rivers

covered timeframe:

$2015-2016$

\section{Site specifications}

coordinate system/grid data:

grid data available:

site coding available:

example:

number of sites:

exact number of sites: latitude/longitude, format: DD

no

yes, alphanumerical

RCS1504

$100-1000$

101

\section{Climate and environmental data}

climate related data:

environmental data:

available parameters per site: no climate data available

no environmental data per catchment available

information on riparian vegetation (incl. information on modification) data source: field measurement

information on cross section (incl. information on modification)

data source: field measurement 
comments:

physico-chemical data:

stressors influencing the sites:

comments:

\section{Biological data}

biological data origin:

comments:

organism group addressed: current velocity

data source: field measurement

mean depth

data source: field measurement

wetted width

data source: field measurement

substrate composition

data source: field measurement

information on instream habitat (incl. information on modification)

data source: field measurement

Information on riparian vegetation includes percentage riparian vegetation left $\&$ right bank; and percentage of canopy cover over sampled area.

Information on instream habitat includes the percentage pool, riffle, and run.

Substrate composition recorded as: bedrock -6 , cobble $(6-25 \mathrm{~cm})-5$, gravel

$(2-60 \mathrm{~mm})-4$, sand $(0.06-2 \mathrm{~mm})-3$, mud/silt $(<0.06 \mathrm{~mm})-2$, clay/detritus -1 .

oxygen content, water temperature, $\mathrm{pH}$

no stressor data available

All physico-chemical variables were measured in the field.

from sampling,

Freshwater community dynamics in the Northern Ewaso Ng'iro in Kenya

Fishes and environmental data were collected during RCS's postdoctoral project funded by the Smithsonian Institution.

fish

\section{Sample specifications/sample resolution}

\section{fish:}

sample information:

covered timeframe: 2015-2016

season: spring, summer, autumn, winter

temporal resolution/frequency of sampling:

\section{taxonomic resolution:}

per month

level:

genus, species

percentage of species level data: 99

comments:

All organisms were determined to species level except for one undescribed Haplochromis sp.

taxonomic coding:

taxalist according to:

reference(s):

\section{sample specifications:}

type:
Nyingi 2013

Nyingi, W.D. 2013. A guide to common freshwater fishes of Kenya. Moran Publishers Kenya.

semi-quantitative, presence/absence 
replicate samples: no

number of samples: $\quad 101$

specification of method(s) used for sampling and sorting:

Fishes were sampled with seines and electrofishers. Each locality was sampled for 45 minutes to one and one-half hours to ensure all habitat types were sampled.

\title{
Other specifications
}

\section{GIS layers, shape files related to the dataset:}

\author{
no data available \\ availability of photos: yes \\ availability of maps: yes \\ quality control procedures: \\ Were any quality control procedures applied to your dataset?
}

no

\section{Acknowledgements}

This research would not have been possible without the support of researchers and staff at the National Museums of Kenya (NMK) and Mpala Research Centre (MRC). Funding for this research was provided by the Mpala Smithsonian Postdoctoral Fellowship awarded to RCS. Scott Miller and Ben Turner (Smithsonian Institution) served as postdoctoral advisers to RCS. Dino Martins, Cosmas Nzomo, and Juilus Nakolonyo (MRC) assisted RCS in permitting, logistics, field collections, and security. Joseph Gathua, Kilbert Gosgei, and Caroline Kibet assisted with field collections, identifications, and deposition of material at NMK. Verity Williams, proprietor of Sabuk Lodge, graciously allowed access to her property to sample the river below the site of proposed dam. Staff in the Division of Fishes in the National Museum of Natural History assisted with processing loaned specimens associated with this project.

\section{References}

Nyingi, W.D., 2013. Guide to Common Freshwater Fishes of Kenya. Moran (E.A.) Publishers Limited. 136 pages 